\title{
Erratum to: When Quality Trumps Quantity: Siblings and the Development of Peer Relationships
}

\author{
Deniz Yucel • Douglas B. Downey
}

Published online: 4 February 2015

(C) Springer Science+Business Media Dordrecht 2015

\section{Erratum to: Child Ind Res (2014) \\ DOI 10.1007/s12187-014-9276-0}

The published article unfortunately contained errors in Tables 1 and 3. These tables are corrected as follows:

The online version of the original article can be found at http://dx.doi.org/10.1007/s12187-014-9276-0.

D. Yucel $(\bowtie)$

Department of Sociology, William Paterson University of New Jersey, 300 Pompton Road, 465,

Raubinger Hall, Wayne, NJ 07470, USA

e-mail: yuceld@wpunj.edu

\section{B. Downey}

Department of Sociology, The Ohio State University, 238 Townshend Hall, 1885 Neil Ave. Mall, Columbus, OH 43210, USA

e-mail: downey32@gmail.com 
Table 1 Descriptive statistics of all variables from wave 1 of "understanding society" data $(N=4899)$

\begin{tabular}{|c|c|c|c|c|}
\hline Variables & $\begin{array}{l}\text { Mean/ } \\
\text { percentages* }\end{array}$ & $\begin{array}{l}\text { Standard } \\
\text { deviation }\end{array}$ & Metric & Description \\
\hline
\end{tabular}

Dependent variable

Peer relationship quality
1.65

$0-10$

Independent variable

$\begin{array}{lccc}\text { No sibling } & 0.14 & - & 0-1 \\ \text { One sibling } & 0.42 & - & 0-1 \\ \text { Two siblings } & 0.27 & - & 0-1 \\ \text { Three siblings } & 0.11 & - & 0-1 \\ \begin{array}{l}\text { Four siblings } \\ \text { At least five } \\ \text { siblings }\end{array} & 0.04 & - & 0-1 \\ & 0.02 & - & 0-1\end{array}$

Different dimensions of sibship

\begin{tabular}{|c|c|c|}
\hline $\begin{array}{c}\text { Number of } \\
\text { brothers }\end{array}$ & 0.79 & 0.84 \\
\hline Number of sisters & 0.77 & 0.81 \\
\hline Full siblings & 1.38 & 1.06 \\
\hline
\end{tabular}

This study uses the Strengths and Difficulties Questionnaire (SDQ). Originally, the SDQ is made up of 25 items, which measures both negative and positive behaviors in children. Each item is scored on a 3-point Likert-type scale. Items are rescaled and positive behaviors were reverse coded. Five items each are aggregated into five subscales (emotional problems, conduct problems, hyperactivity/ inattention, peer relationship problems, and pro-social behavior). For this study, we only use the scale on peer relationship problems. To measure peer relationship problems, the following five questions are asked. i) "Usually on own. Generally plays alone or keeps to themselves." ii) "Has one good friend or more." iii) "Generally liked by others own age." iv) "Other children or young people pick on or bully." v) "Gets on better with adults." The SDQ was completed by the young person as part of the self-completion questionnaire. The youth responded to questions as "Not true" "Somewhat true" or "Certainly true". Responses were coded as 0 , 1 , and 2. Items 1,4 , and 5 are reverse coded. The total scale ranges from 0 to 10 , with higher scores indicating better peer relationships. The alpha for this scale is moderate with an alpha of 0.52 .

Having no sibling living in the household $(0=$ No, 1 = Yes)

Having one sibling living in the household $(0=$ No, 1 = Yes)

Having two siblings living in the household $(0=$ No, 1 = Yes)

Having three siblings living in the household $(0=$ No, $1=$ Yes $)$

Having four siblings living in the household $(0=$ No, 1 = Yes)

Having at least five siblings living in the household $(0=$ No, $1=$ Yes $)$

Total number of brothers living in the household

Total number of sisters living in the household

Total number of full siblings living in the household 
Table 1 (continued)

\begin{tabular}{|c|c|c|c|c|}
\hline Variables & $\begin{array}{l}\text { Mean/ } \\
\text { percentages* }\end{array}$ & $\begin{array}{l}\text { Standard } \\
\text { deviation }\end{array}$ & Metric & Description \\
\hline Half siblings & 0.11 & 0.39 & $0-2$ & $\begin{array}{l}\text { Total number of half siblings living in the } \\
\text { household }\end{array}$ \\
\hline Step siblings & 0.02 & - & $0-1$ & $\begin{array}{l}\text { Having a step sibling living in the household } \\
\quad(0=\text { No, } 1=\text { Yes })\end{array}$ \\
\hline $\begin{array}{l}\text { Adopted or foster } \\
\text { siblings }\end{array}$ & 0.01 & - & $0-1$ & $\begin{array}{l}\text { Having adopted/foster sibling living in the } \\
\text { household } \\
(0=\text { No, } 1=\text { Yes })\end{array}$ \\
\hline $\begin{array}{l}\text { Siblings who are } \\
\text { under } 10 \text { years } \\
\text { old }\end{array}$ & 0.58 & 0.81 & $0-3$ & $\begin{array}{l}\text { Total number of siblings living in the household } \\
\text { who are under } 10 \text { years old }\end{array}$ \\
\hline $\begin{array}{l}\text { Siblings who are } \\
\text { between } 10 \text { and } \\
15 \text { years old }\end{array}$ & 0.59 & 0.65 & $0-2$ & $\begin{array}{l}\text { Total number of siblings living in the household } \\
\text { who are between } 10 \text { and } 15 \text { years old }\end{array}$ \\
\hline $\begin{array}{l}\text { Siblings who are } \\
\text { older than } \\
15 \text { years old }\end{array}$ & 0.41 & 0.64 & $0-2$ & $\begin{array}{l}\text { Total number of siblings living in the household } \\
\text { who are older than } 15 \text { years old }\end{array}$ \\
\hline $\begin{array}{l}\text { Sibling } \\
\text { relationship } \\
\text { quality }\end{array}$ & 25.35 & 5.87 & $8-32$ & $\begin{array}{l}\text { Target children were asked: "How often do any } \\
\text { of your brothers or sisters do any of the } \\
\text { following to you at home?" with the options } \\
\text { "hit, kick, or push you", 'take your } \\
\text { belongings", "call you nasty names" and } \\
\text { "make fun of you". Response categories } \\
\text { determine the frequency of each option: } \\
\text { "never", "not much (1-3 times in the last } \\
6 \text { months)", "quite a lot (more than } 4 \text { times in } \\
\text { the last } 6 \text { months)", "a lot (a few times every } \\
\text { week)". These items are first reverse coded } \\
\text { and then added so that higher number on this } \\
\text { scale indicates less victimization of sibling } \\
\text { bullying. Following these questions, children } \\
\text { were asked whether they were the perpetrator } \\
\text { of bullying towards their siblings "How often } \\
\text { do you do any of the following to your } \\
\text { brothers or sisters at home?" with the same } \\
\text { options and response categories as mentioned } \\
\text { above. These items are first reverse coded } \\
\text { and then added so that higher number on this } \\
\text { scale indicates less report of being a } \\
\text { perpetuator of sibling bullying. These two } \\
\text { groups of questions (being the victim and } \\
\text { perpetuator of sibling bullying) were added } \\
\text { together. Alpha = .80. }\end{array}$ \\
\hline $\begin{array}{l}\text { Child's age in } \\
\text { years }\end{array}$ & 12.78 & 1.40 & $10-15$ & $\begin{array}{l}\text { Child's age in years. } \\
\text { (Target child is between } 10 \text { and } 15 \text { years of } \\
\text { age). }\end{array}$ \\
\hline Parent's age & 42.53 & 5.71 & $25-65$ & $\begin{array}{l}\text { Average of both parent's age } \\
\quad \text { (in years) }\end{array}$ \\
\hline $\begin{array}{l}\text { Mother with a } \\
\text { degree }\end{array}$ & 0.20 & - & $0-1$ & $(0=$ No, $1=$ Yes $)$ \\
\hline
\end{tabular}


Table 1 (continued)

\begin{tabular}{|c|c|c|c|c|}
\hline Variables & $\begin{array}{l}\text { Mean/ } \\
\text { percentages* }\end{array}$ & $\begin{array}{l}\text { Standard } \\
\text { deviation }\end{array}$ & Metric & Description \\
\hline $\begin{array}{l}\text { Mother with A } \\
\text { levels or higher }\end{array}$ & 0.32 & - & $0-1$ & $(0=$ No, $1=$ Yes $)$ \\
\hline $\begin{array}{l}\text { Mother with GSCE O } \\
\text { level }\end{array}$ & 0.26 & - & $0-1$ & $(0=$ No, $1=$ Yes $)$ \\
\hline $\begin{array}{l}\text { Mother with less } \\
\text { than GCSE level } \\
\text { (reference) }\end{array}$ & 0.22 & - & $0-1$ & $(0=$ No, $1=$ Yes $)$ \\
\hline $\begin{array}{l}\text { Father with a } \\
\text { degree }\end{array}$ & 0.24 & - & $0-1$ & $(0=\mathrm{No}, 1=\mathrm{Yes})$ \\
\hline $\begin{array}{l}\text { Father with A } \\
\text { levels or higher }\end{array}$ & 0.31 & - & $0-1$ & $(0=$ No, $1=$ Yes $)$ \\
\hline $\begin{array}{l}\text { Father with GSCE } \\
\text { O level }\end{array}$ & 0.21 & - & $0-1$ & $(0=\mathrm{No}, 1=\mathrm{Yes})$ \\
\hline $\begin{array}{l}\text { Father with less } \\
\text { than GCSE level } \\
\text { (reference) }\end{array}$ & 0.24 & - & $0-1$ & $(0=$ No, $1=$ Yes $)$ \\
\hline $\begin{array}{l}\text { Socioeconomic } \\
\text { status (log of } \\
\text { family income) }\end{array}$ & 7.96 & 0.87 & $\begin{array}{l}0-20,000 \\
\text { British } \\
\text { Pound }\end{array}$ & $\begin{array}{l}\text { Gross monthly household income (month before } \\
\text { the interview). It has a skewed distribution, } \\
\text { therefore I took the log of the income } \\
\text { measure. }\end{array}$ \\
\hline White (reference) & 0.73 & - & $0-1$ & $(0=$ No, $1=$ Yes $)$ \\
\hline Asian & 0.14 & - & $0-1$ & $(0=$ No, $1=$ Yes $)$ \\
\hline Other race & 0.13 & - & $0-1$ & $(0=$ No, $1=$ Yes $)$ \\
\hline Male & 0.50 & - & $0-1$ & $(0=$ No, $1=$ Yes $)$ \\
\hline Number of friends & 5.58 & 2.71 & $0-9$ & "How many close friends do you have?" \\
\hline Mother's health & 3.44 & 1.09 & $1-5$ & $\begin{array}{l}(1=\text { Poor, } 2=\text { Fair, } 3=\text { Good } \\
\quad 4=\text { Very Good, } 5=\text { Excellent })\end{array}$ \\
\hline Father's health & 3.53 & 1.06 & $1-5$ & $\begin{array}{l}(1=\text { Poor, } 2=\text { Fair, } 3=\text { Good } \\
\quad 4=\text { Very Good, } 5=\text { Excellent })\end{array}$ \\
\hline $\begin{array}{l}\text { Two biological } \\
\text { parents }\end{array}$ & 0.59 & - & $0-1$ & $\begin{array}{l}1=\text { Lives with two biological parents, } 0= \\
\text { everything else. }\end{array}$ \\
\hline $\begin{array}{l}\text { Parent-child } \\
\text { relationship }\end{array}$ & 3.17 & 0.50 & 1.5 to 4 & $\begin{array}{l}\text { As part of the youth questionnaire; children are } \\
\text { asked the following six questions. 1) "How } \\
\text { often do you quarrel with your mother?" 2) } \\
\text { "How often do you quarrel with your father?" } \\
\text { 3) "How often do you talk to mother about } \\
\text { things that matter?" 4) "How often do you } \\
\text { talk to father about things that matter?" The } \\
\text { answer categories are from "most days", } \\
\text { "more than once a week", "less than once a } \\
\text { week" and "hardly ever." In addition, the } \\
\text { following two questions are asked. 5) "How } \\
\text { often are your parents interested in how you } \\
\text { do at school?" 6) "How often do your parents } \\
\text { attend parent's evenings at school?" The } \\
\text { answer categories for these two questions are } \\
\text { "always or nearly always", "sometimes", } \\
\text { "hardly ever", and "never." Questions } 2-6 \text { are } \\
\text { reverse coded so that higher scores indicate }\end{array}$ \\
\hline
\end{tabular}


Table 1 (continued)

\begin{tabular}{|c|c|c|c|c|}
\hline Variables & $\begin{array}{l}\text { Mean/ } \\
\text { percentages* }\end{array}$ & $\begin{array}{l}\text { Standard } \\
\text { deviation }\end{array}$ & Metric & Description \\
\hline & & & & $\begin{array}{l}\text { better parent-child relationship. These six } \\
\text { items are summed and averaged. Higher } \\
\text { number on this scale represents better parent- } \\
\text { child relationship. Alpha of the six questions } \\
0.63 \text {, which indicates an acceptable } \\
\text { consistency. }\end{array}$ \\
\hline
\end{tabular}

* Percentages rather than means are presented for the nominal (categorical) variables. These unweighted descriptive statistics are derived from one of the five datasets with imputed missing values 


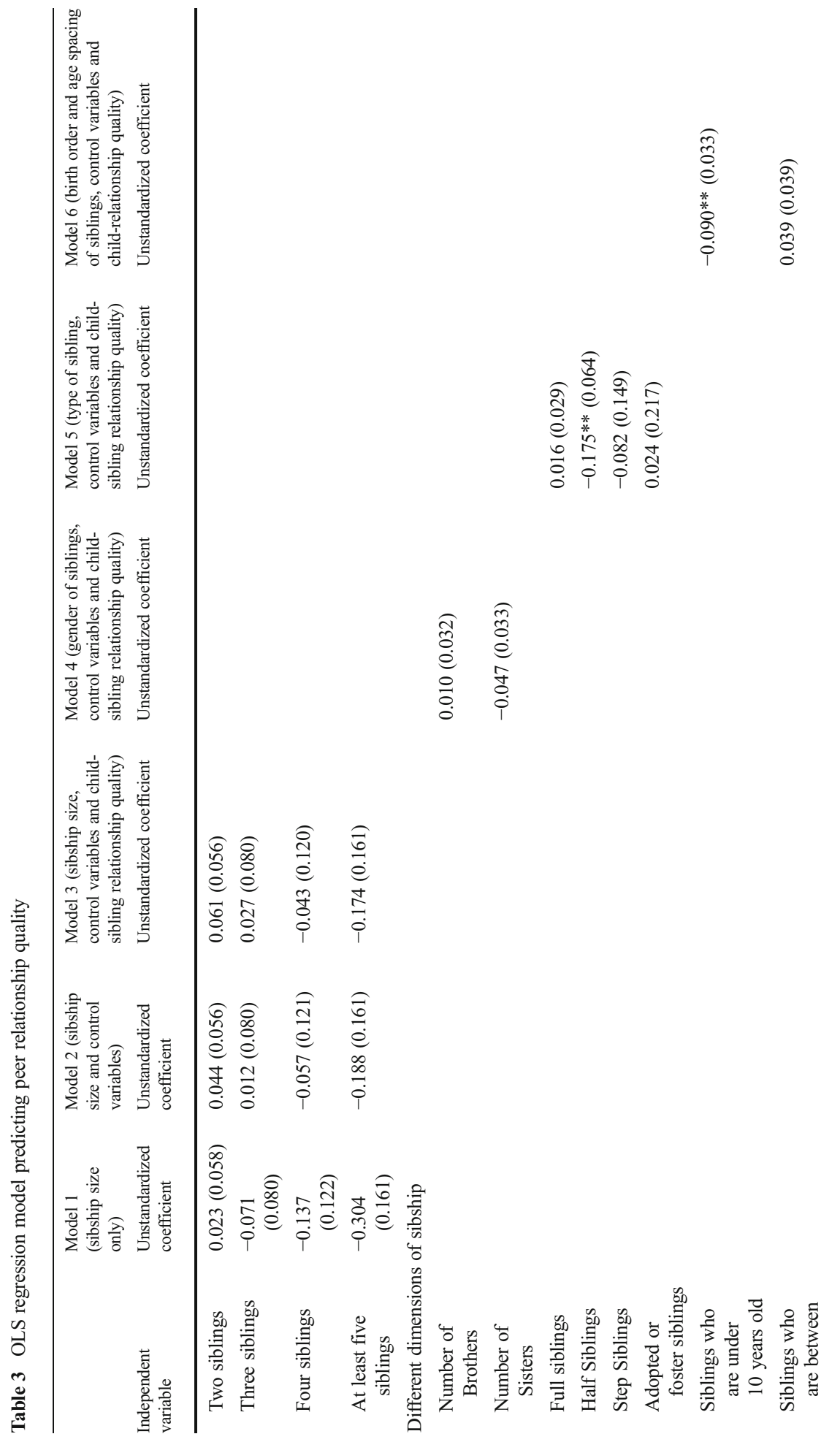




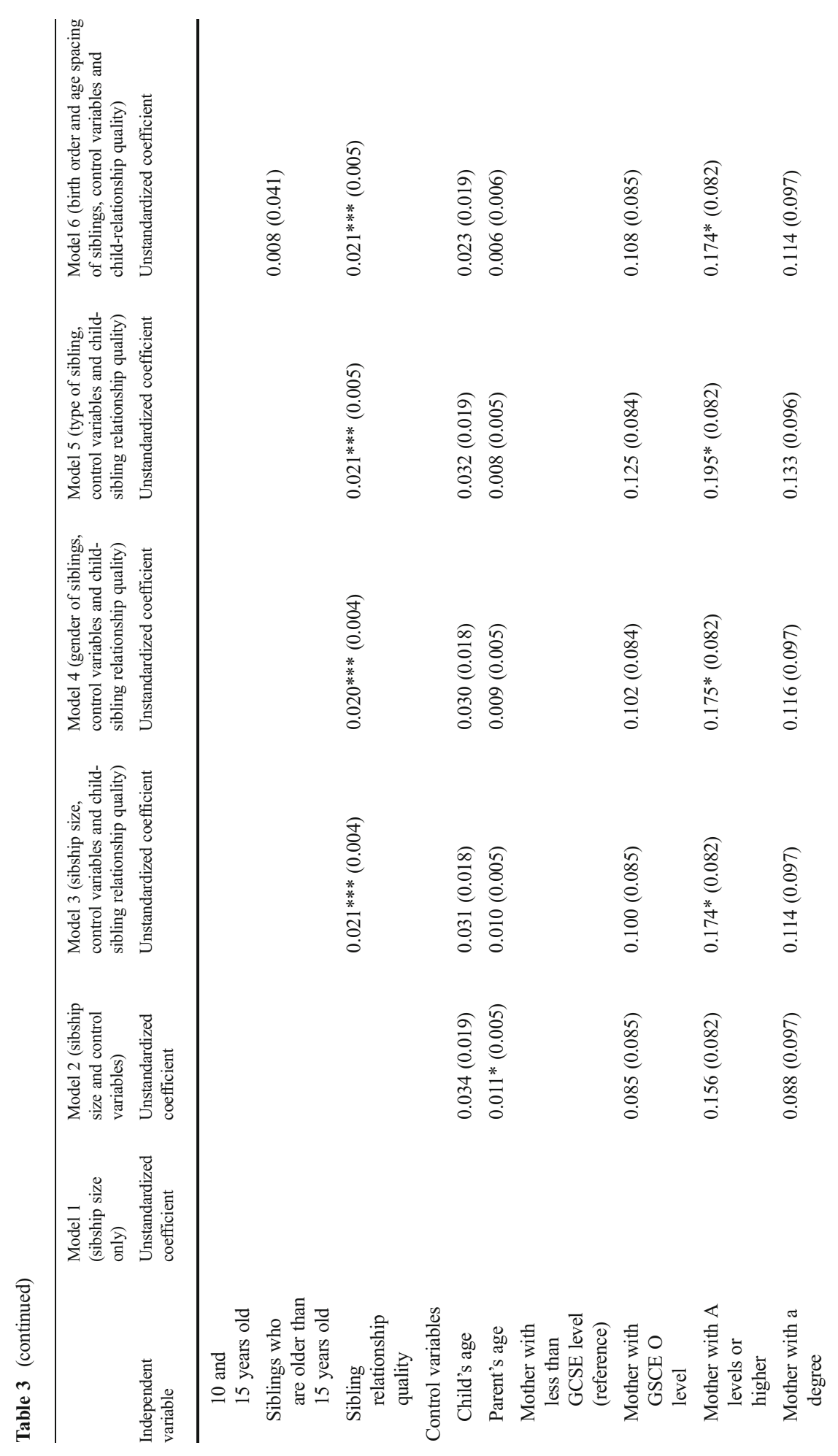




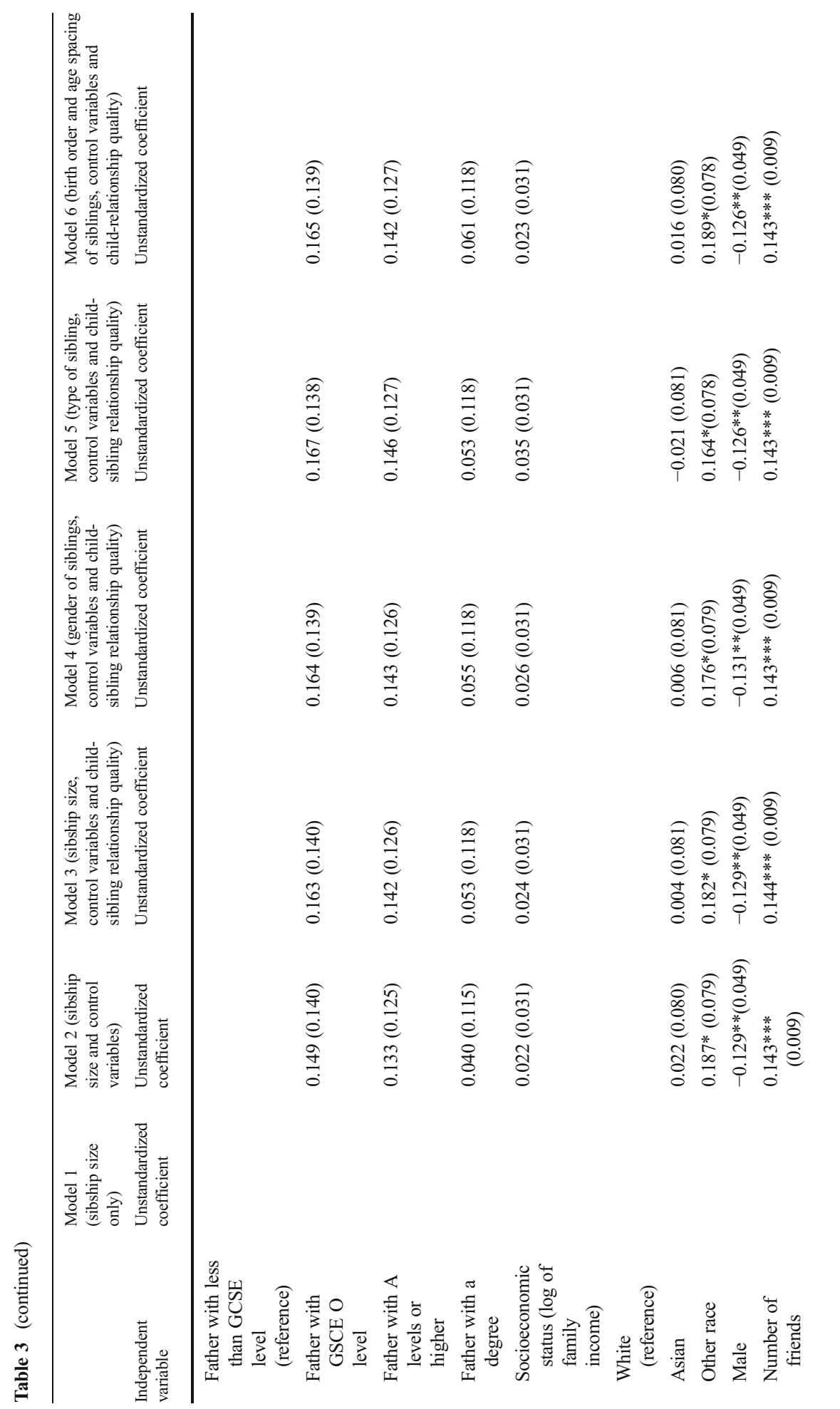




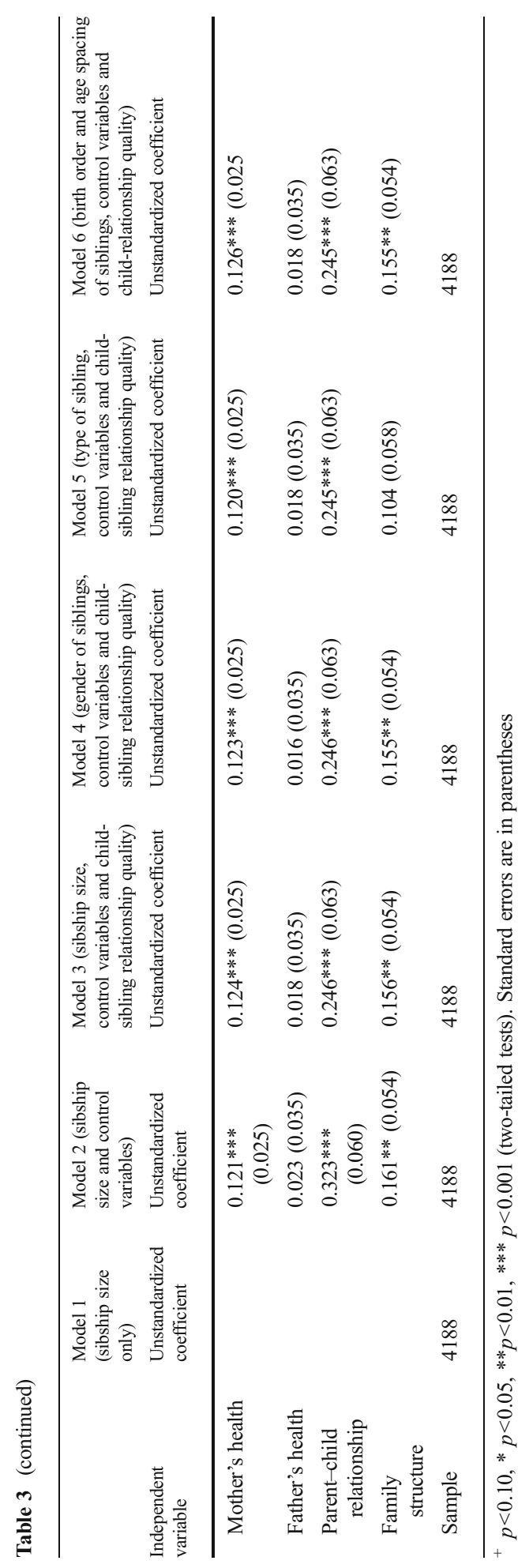

